\title{
GRASS POLLEN (POACEAE) IN THE AIR OF SOSNOWIEC (POLAND), $1997-2006$
}

\author{
Kazimiera Chłopek \\ University of Silesia, Faculty of Earth Sciences, Będzińska 60, 41-200 Sosnowiec, Poland \\ e-mail: chlopek@wnoz.us.edu.pl
}

Received: 24.09 .2007

S u m m a r y

The article presents the analysis results of the grass pollen seasons from 1997 to 2006 in Sosnowiec. The research was carried out by means of the volumetric method with the use of a Burkard device. The duration of the pollen seasons was determined by means of the $98 \%$ method. The influence of meteorological conditions on the starting date and duration of the grass pollen seasons has been estimated in the article. The beginning of the pollen seasons was recorded between 23 April and 23 May. It has been demonstrated that the average duration of the pollen season amounted to 138 days. The period of maximum concentrations was recorded in June and the first half of July. The highest daily concentration was found in 2000 (495 grains in $\left.\mathrm{m}^{3}\right)$ and the highest annual sums in 2002 and 2000. The daily concentration distribution curve has shown three peaks. The highest values were recorded from 7 am until $11 \mathrm{am}$, from $13 \mathrm{pm}$ until $17 \mathrm{pm}$ and from $19 \mathrm{pm}$ until $21 \mathrm{pm}$. It has been found that there is a significant influence of weather conditions (temperature, precipitation and relative humidity) on the beginning and duration of the pollen seasons and the period of maximum concentrations.

Key words: grass pollen, pollen season, pollen concentration, meteorological factors, Sosnowiec

\section{INTRODUCTION}

Grasses are a natural component of flora. They grow almost everywhere: in forests, on meadows, sand dunes, steppes, in deserts, in the mountains, in lowlands in different climate zones. They are perennial or annual, wind-pollinated, herbaceous plants. Approximately 160 species of grasses can be found in Poland. Cultivated grasses, mainly corn, also belong to the grass family. Grass flowering biology is characterized by great diversity both between species and within one species. The duration of flowering depends on the diversity of this population and weather conditions. Particular species flower during the time of the day which is specific to them and in specific thermal and humidity conditions (B o c h n i a r z, 1960; R u t k ow s k a, 1970). The pollination season is long - it lasts from May to the end of September - because of a great number of grass species.

Grass pollen allergens are responsible for the most frequent causes of pollinosis in many European countries (S p i e k s m a, 1989; B e r g e r, 2003). In Europe, an allergy to grass pollen is found more often than to the pollen of other plants. It is also the main cause of pollinosis in Poland (Ligęziński and Rapiejko, 1994; Ś p i e w a k, 2001). Over $90 \%$ of the population suffers during grass flowering $(\mathrm{O} \mathrm{b} \mathrm{t} \mathrm{u} \mathrm{o} \mathrm{w} \mathrm{i} \mathrm{c} \mathrm{z} \mathrm{et} \mathrm{al.}$ 1990). Disease symptoms caused by grass pollen allergens develop in some patients when a concentration value in a cubic metre of air exceeds 20 grains in $\mathrm{m}^{3}$, and in all of them when they are exposed to a concentration of over 50 grains in $\mathrm{m}^{3}$ ( $\mathrm{R} \mathrm{a} \mathrm{p} \mathrm{i} \mathrm{e} \mathrm{j} \mathrm{k} \mathrm{o} \mathrm{et} \mathrm{al.} \mathrm{2004a).}$ These values are treated as medium and high, but very high concentrations when they exceed 100 grains in $\mathrm{m}^{-3}$ of air (R a p i e j k o, 2003).

The results of the ten-year research on grass pollen in Sosnowiec are presented in the article. When analysing them, particular attention was paid to the variability in pollen concentrations during grass vegetation and to the course of the pollen seasons depending on weather conditions in the years discussed.

\section{MATERIALS AND METHODS}

The aeropalynological study in Sosnowiec was carried out from 1997 to 2006 by means of the volumetric method with the use of a Burkard device. A trap site is located at a height of 20 metres on the University of Silesia premises in the district characterized by dispersed blocks of flats, near allotments at the junction of two arteries. The duration of the grass pollen seasons was determined by means of the $98 \%$ method (E $\mathrm{m}$ b e r 1 in 
et al. 1993). Data from the Meteorological Observatory and the Environment Dynamics Laboratory in the Faculty of Earth Sciences at the University of Silesia were used to determine the relationships between the pollen seasons and meteorological conditions - average, minimum and maximum temperature of air, relative humidity and rainfall. The degree of correlation between meteorological parameters and grass concentrations was described by the Pearson's correlation.

\section{RESULTS}

Considerable variability in the course of the grass pollen seasons regarding the beginning and duration of the pollen season, maximum concentration values and the period of their occurrence was found during the tenyear pollen monitoring conducted in Sosnowiec. The concentration of wild grass and corn pollen was jointly monitored over all the years of study. With regard to corn, only rye pollen was found in small quantities.

Grass pollen in the air of Sosnowiec was noticed from late April to the end of September. The average duration of the pollen season over a period of ten years amounted to 138 days. The longest pollen seasons, which lasted 154 days, were recorded in 1998 and 2001, the shortest pollen season, which lasted 123 days, was noted in 2003 (Tab. 1).

During the decade discussed, the grass pollen season was recorded earliest on 23 April in 1999 and 2000, and latest in 1997 - as late as 23 May. In 2005 and 2006, it was recorded in mid May and in the remaining years - in early May (Tab. 1). The beginnings of the pollen seasons differed by one to thirty days. The weather conditions, particularly temperature, sunshine and relative humidity, influenced the beginning of the grass pollen season. A positive correlation was found with the average temperature of April and May and the maximum temperature of April. In 1999 and 2000, the high temperatures of April $\left(14.8^{\circ} \mathrm{C}-20.3^{\circ} \mathrm{C}\right)$ and May $\left(15.5^{\circ} \mathrm{C}-21.4^{\circ} \mathrm{C}\right)$ resulted in earlier vegetation of grass and the presence of pollen in the atmosphere (Fig. 1). The average temperatures of April and May in 1997 were $10^{\circ} \mathrm{C}$ and $13.7^{\circ} \mathrm{C}$ - the pollen season was recorded latest in the years discussed.

Over the period of ten years, the grass pollen concentration dynamics showed some differences (Figs 1-3). One can distinguish a few growth stages of the pollen concentration by the analysis of the course of grass pollination in particular years. In 1999, 2000 and 2002, the first growth stage with a medium and high pollen concentration was recorded as early as the first half of May. In the remaining years, it was recorded in the second half of May with the exception of 1998. The next distinct concentration increase was observed in June and July, when the highest concentrations during twenty-four hours were recorded. The maximum daily grass pollen concentrations were recorded in 1997 and 2000-2003 between 5 and 15 June, in 1999 and 20042006 in the first half of July, and in 1998 not until late July (Figs 1-3). In the period of maximum grass pollination, there were days characterized by low pollen concentration values, which was caused by a few days' heavy rainfall. It brought about a halt or delay in grass flowering by a few days. Since the middle of July, the grass pollen concentration gradually decreased, reaching medium and low values. The high pollen concentration lasted longest in 2005 - until 2 August - as well as in 1998, 2004 and 2006 until the end of July (Figs 1-3). The differences in the periods of maximum concentrations were caused by the weather conditions in the study years, particularly by rainfall, relative humidity and a temperature drop.

Table 1

Characteristics of grass (Poaceae) pollen seasons in Sosnowiec, 1997-2006.

\begin{tabular}{|c|c|c|c|c|c|}
\hline \multirow{2}{*}{ Year } & \multicolumn{2}{|c|}{ Length of pollen season } & \multirow{2}{*}{$\begin{array}{l}\text { Maximum of pollen } \\
\text { grains } \times \mathrm{m}^{-3} \times 24 \mathrm{~h}\end{array}$} & \multirow{2}{*}{$\begin{array}{c}\text { Date of maximum } \\
\text { concentration }\end{array}$} & \multirow{2}{*}{$\begin{array}{c}\text { Annual } \\
\text { total }\end{array}$} \\
\hline & Period & Days & & & \\
\hline 1998 & 23.05. - 1.10. & 131 & 211 & 11.06. & 5155 \\
\hline 1997 & 9.05. - 10.10 & 154 & 101 & 22.07. & 1770 \\
\hline 1999 & 23.04. - 20.09. & 149 & 316 & 4.07. & 4145 \\
\hline 2000 & 23.04. - 9.09. & 139 & 495 & 22.06 . & 6451 \\
\hline 2001 & $9.05 .-10.10$ & 154 & 136 & 6.06 & 3257 \\
\hline 2002 & $3.05 .-6.09$ & 126 & 328 & 5.06 & 6504 \\
\hline 2003 & $8.05 .-8.09$ & 123 & 146 & 15.06. & 5019 \\
\hline 2004 & $9.05 .-15.09$ & 129 & 257 & 8.07 & 5156 \\
\hline 2005 & 16.05. - 19.09. & 126 & 281 & 3.07 . & 4525 \\
\hline 2006 & 12.05. - 4.10. & 145 & 259 & 2.07 . & 4168 \\
\hline
\end{tabular}




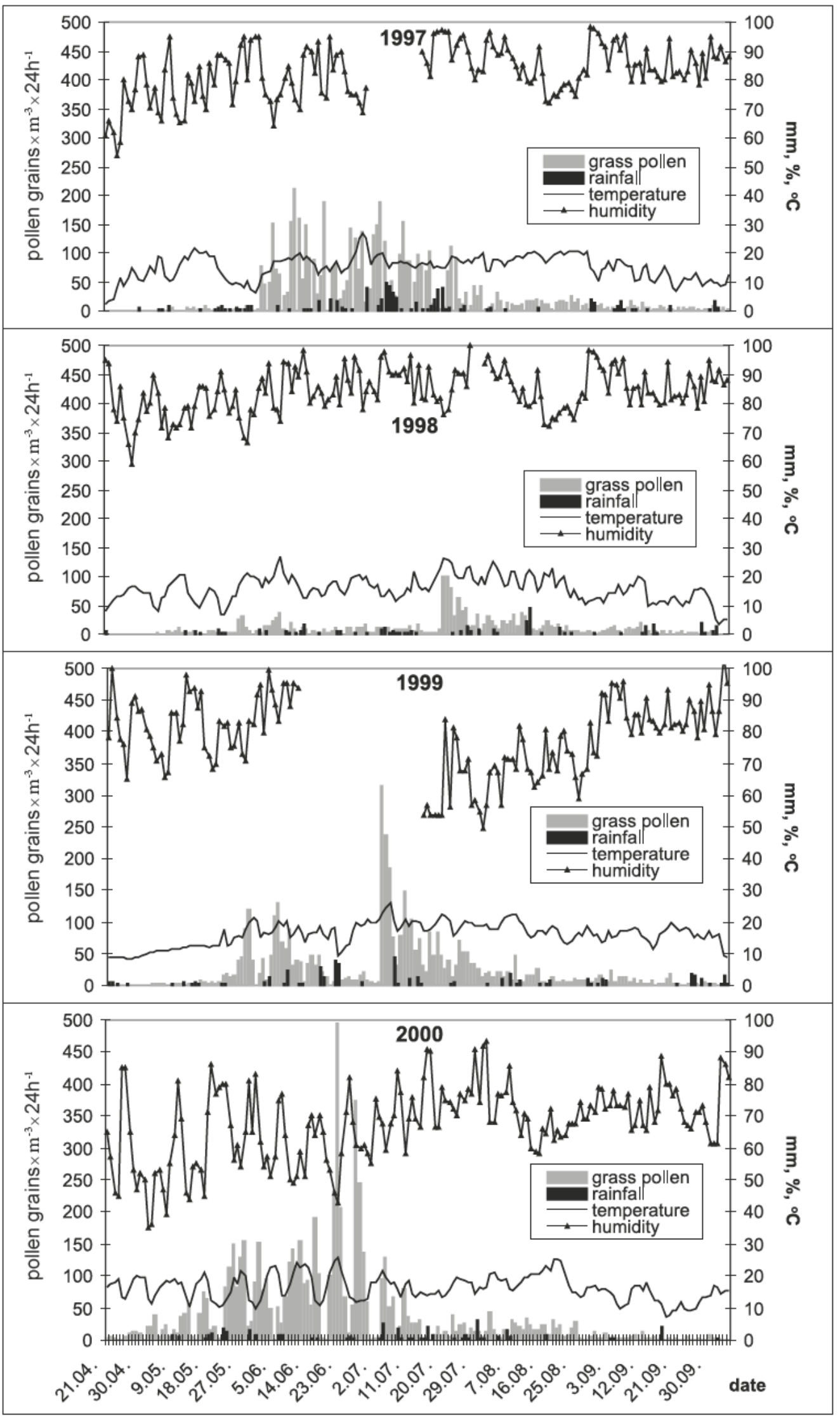

Fig. 1. Seasonal variation in grass pollen concentrations in Sosnowiec in relation to selected weather factors. 


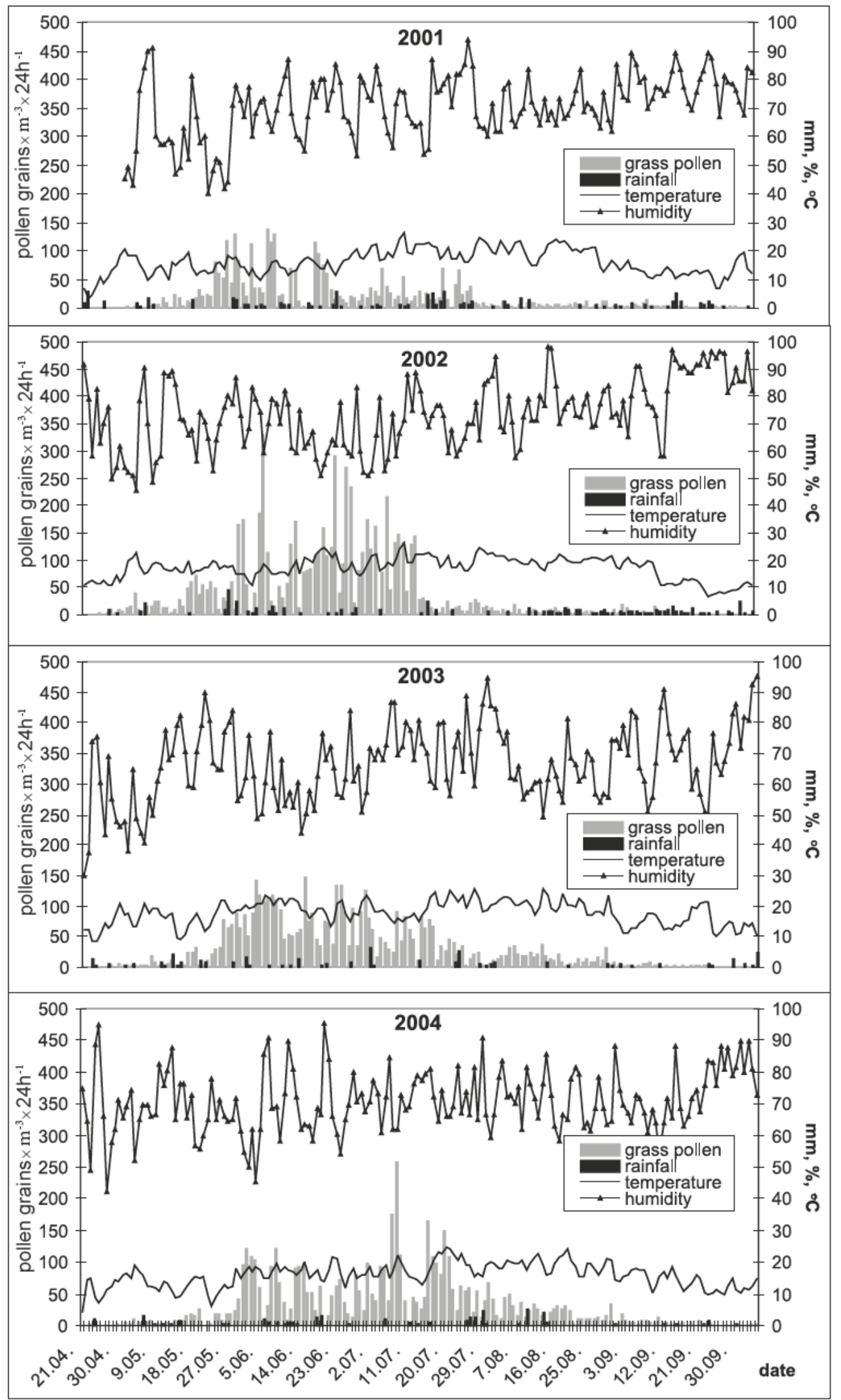

Fig. 2. Seasonal variation in grass pollen concentrations in Sosnowiec in relation to selected weather factors. 


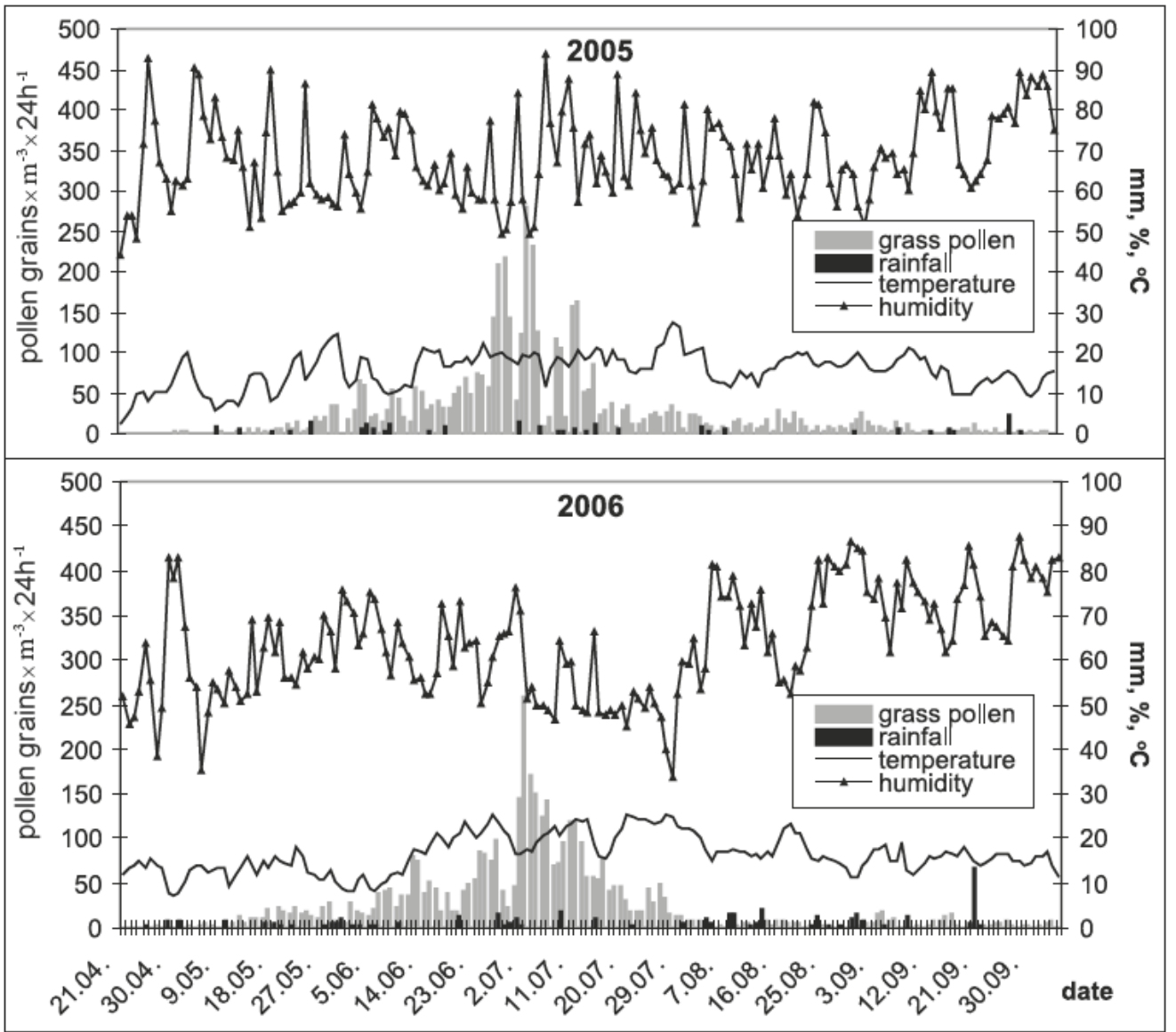

Fig. 3. Seasonal variation in grass pollen concentrations in Sosnowiec in relation to selected weather factors.

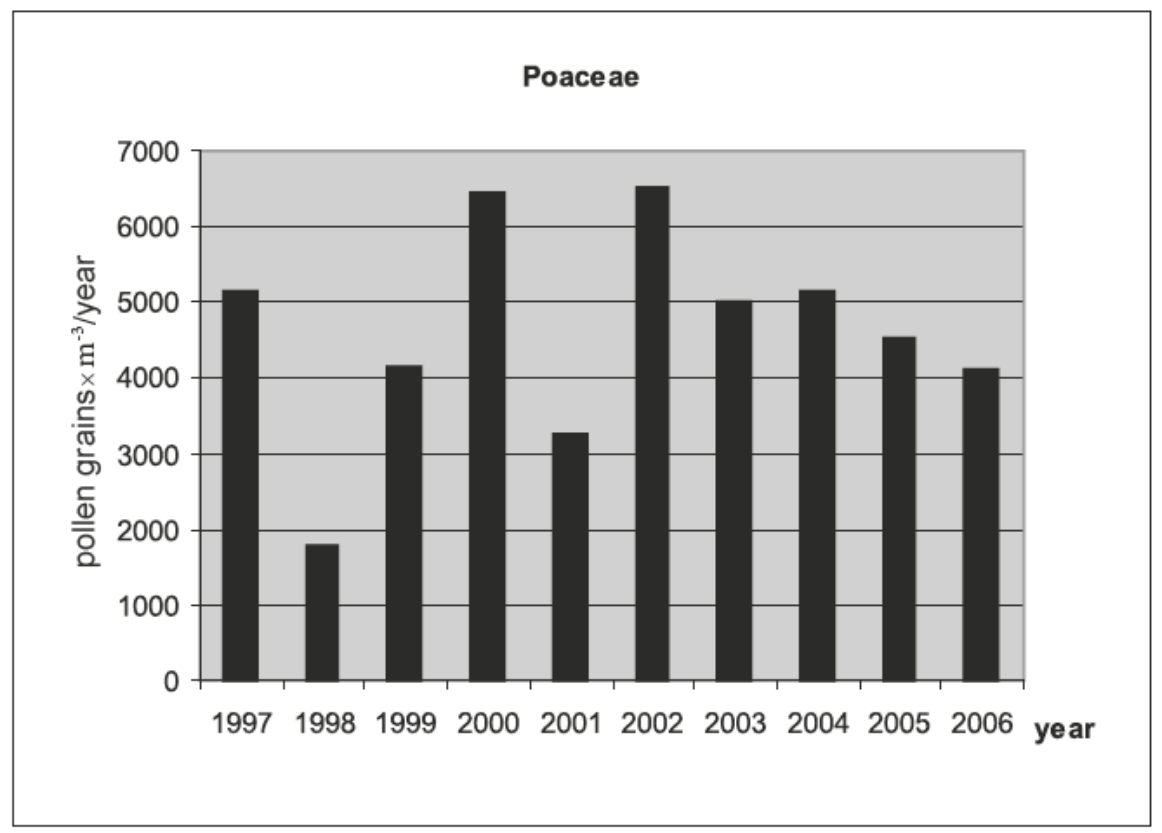

Fig. 4. Annual totals of grass pollen in Sosnowiec in $1997-2006$. 
The highest grass pollen seasonal maximum was recorded in 2000 (495 grains in $\mathrm{m}^{3}$ ), the lowest in 1998 (101 grains in $\mathrm{m}^{3}$ ). The highest annual sums were recorded in 2002 and 2000, the lowest annual sum was recorded in 1998 (Tab. 1). The annual sums did not differ significantly, with the exception of 2001 and 1998 (Fig. 4). In these years, the sums were twofold and fourfold lower than in the remaining years. 1998 and 2001 were characterized by the longest pollen season, but the lowest annual sums and the lowest concentrations during twenty-four hours over the ten years discussed. It was found that temperature and sunshine influenced the level of the average daily concentration. The concentration increased together with a rise in temperature and sunshine, and it decreased together with a rise in relative humidity.
Grass pollen in the atmosphere of Sosnowiec was found twenty-four hours a day. The graph of diurnal curves was irregular and with many peaks. The highest pollen concentrations during twenty-four hours (ten years' average) were recorded between 7 am -11 am, $1 \mathrm{pm}-5 \mathrm{pm}$ and $7 \mathrm{pm}-9 \mathrm{pm}$. A distinct decrease was observed between $11 \mathrm{pm}-1$ am and $4 \mathrm{am}-5 \mathrm{am}-$ then the presence of pollen in the air was the lowest. In the study years, there were differences in the occurrence of maximum concentrations during twenty-four hours, but they fell into the periods listed above. In 1997, the highest concentration was found at $7 \mathrm{pm}$, in 1998 - at $2 \mathrm{pm}$ and $11 \mathrm{pm}$, in 1999, 2005 and 2006 - between $7 \mathrm{am}-8$ am (Fig. 5).

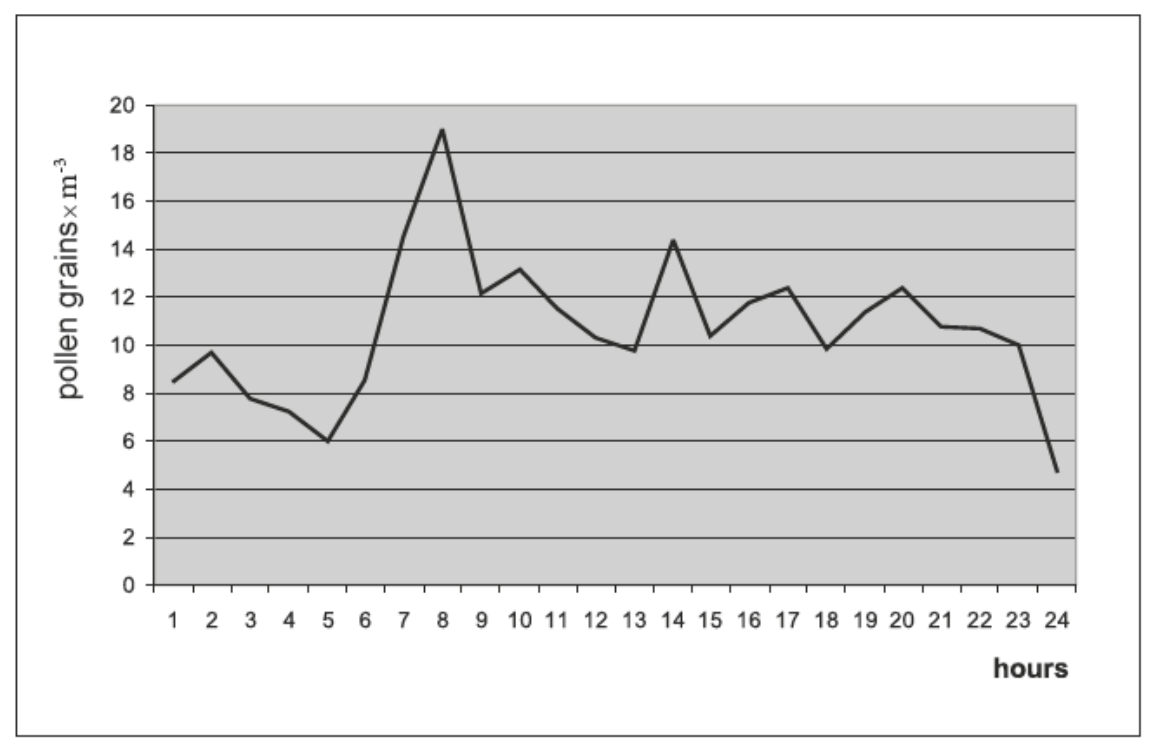

Fig. 5. Average diurnal periodicity of grass pollen concentrations in 1997-2006.

\section{DISCUSSION}

Grass pollen seasons are characterized by their long duration. The main period of grass pollination in Central Europe lasts from the second half of May to the middle of July, in Northern Europe from the second half of June to August, in Southern Europe and the Mediterranean Region from March to June (R o s s - C o d i $\mathrm{nachs}$ et al. 1992; Syrigou et al. 2003).

During the ten years discussed, the period of maximum grass pollen concentrations in Sosnowiec was recorded from early June to the end of July, like in other Polish cities (K a s p r z y k, 1996, 2006; R a p i e j k o et al. 2003; Pu c and Pu c, 2004; Wer y s z k o- C h m i e lewska and Piotrowska, 2004; Myszkowsk a, 2006; P i o t r o w s k a, 2006; S t a c h, 2006;). In 2000, the earlier beginning of the pollen season and the earlier grass seasonal maximum were recorded all over Poland (R a p i e j k o et al. 2004b). In Sosnowiec, the extreme values of annual sums differed 3.6-fold and of daily concentrations - 5-fold. A big contribution of grass pollen was recorded in Rzeszów (K a s pr zyk, 2006), Lublin (P i otrowska, 2006; WeryszkoChmielewska and Pi otrowska, 2006), Szczecin (P u c and P u c , 2004) and Poznań (S t a c h, 2006). The levels of annual sums and average daily concentrations were several times higher than in Sosnowiec. The lowest values of annual sums and daily concentrations were recorded in Kraków (M y s z k o w s k a, 2006). The similar values of annual sums and daily concentration levels were found in Western Europe (S p i e k s $\mathrm{m}$ a et al. 2003; L i pie c et al. 2006).

Grasses include a lot of species and open their anthers at different times of the day, usually between 3 am and 8 pm (J ones and Stillw at er, 1952). Pollen floats in the air due to the wind and the turbulence of air masses, and it can be present for a long time after the closing of anthers (Norris-Hill and Ember- 
li n, 1991). There were differences between successive years with regard to the variation of the pollen concentration daily curve in Sosnowiec. A rapid increase in the pollen concentration was recorded from 7 am to $9 \mathrm{pm}$. The daily curves in Sosnowiec differ with regard to the occurrence of maximum concentrations when compared with Poznań (S t a c h, 1997; G o 1 i ń s k a, 2006), Rabka (K a s p rzyk et al. 2001), Gdańsk (L a t a $\nmid$ o w a and Gó r a , 1995) and Lublin (P i o t r o w s k a, 2005). However, one can notice that one peak of pollination occurs in the morning and the second peak in the afternoon. The weather conditions (temperature, precipitation, humidity) and also the local factors (urbanization) significantly influence these regional differences.

It has been found that the average and maximum temperature and relative humidity have a considerable impact on the beginning and duration of the pollen season and on the level of maximum daily concentrations. The high temperatures of April and May speed up the grass pollen season beginning and the period of the occurrence of maximum concentrations.

\section{CONCLUSION}

1. The average duration of the grass pollen season over a period of ten years amounted to 138 days. During the decade discussed, the grass pollen season was noticed earliest on 23 April in 1999 and 2000, and latest on 23 May 1997.

2. The weather conditions, particularly temperature, sunshine and relative humidity influenced the beginning of the grass pollen season. A positive correlation was found with the average temperature of April and May and the maximum temperature of April.

3. The period of the maximum concentrations was recorded in June and the first half of July.

4. The highest pollen concentrations during twenty-four hours (ten years' average) were recorded between $7 \mathrm{am}-11 \mathrm{am}, 1 \mathrm{pm}-5 \mathrm{pm}$ and $7 \mathrm{pm}-9 \mathrm{pm}$.

\section{REFERENCES}

B e r g e r W. E., 2003. Overview of allergic rhinitis. Ann Allergy Asthma Immunol. 3: 7-12.

B o c h n i a r z J., 1960. Obserwacje nad biologią kwitnienia traw. / Observations on biology of grass flowering. Rocz. Nauk Roln. Seria A, 83(1): 177-202.

E m b e r 1 i n J., S a v a g e M., J o n e s S., 1993. Annul variations in grass pollen season in London 1961-1990: trends and forecast models. Clin. Exp. Allergy, 23: 911-918.

G o 1 i ń s k a B., 2006. Zmiany stężenia pyłku traw w atmosferze Poznania. / Changes in the concentration of grass pollen in the atmosphere of Poznań. Acta Agrobot. 59: 317-324.

J o n e s M. D., S t i 11 w a t e r O., 1952. Time of day shedding of some hay fever plants. Journ. of Aller. 23: 247-258.
K a s p r z y k I., 1996. Palynological analysis of airborne pollen fall in Ostrowiec Świętokrzyski in 1995. Ann Agric Environ. Med. 3(2): 83-86.

K a s p r z y k I., 2006. Pyłek wybranych taksonów roślin w powietrzu Rzeszowa, 2001-2005. / Pollen of selected plant taxa in the air of Rzeszów, 2001-2005. In: Pyłek roślin w aeroplanktonie różnych regionów Polski. E. Weryszko-Chmielewska (ed.), Katedra i Zakład Farmakognozji z Pracownią Roślin Leczniczych Wydziału Farmaceutycznego Akademii Medycznej w Lublinie, pp. 93-104.

K a s przyk I., H armat a K., Mys zkowska K., Stach A., S t ę p a $1 \mathrm{~s} \mathrm{k}$ a D., 2001. Diurnal variation of chosen airborne pollen at five sites in Poland. Aerobiologia, 17: 327-345.

L a t a ł o w a M., G ó r a M., 1995. Airborne Allergenic pollen in the atmosphere of the Gdańsk-Gdynia area (results for the period 1994-1995). Ann Agric Environ. Med. 3, 2: 109-114.

L i g ę z i ń s k i A., R a p i e j k o P., 1994. Stężenie pyłku roślin w atmosferze Polski. / Airborne pollen concentration in the atmosphere of Poland Pneumonol. Alergol. Pol. 62: 347-351

Lipiec A., Malkiewicz M., Maj J., Puc M., Myszkowska D., Weryszko-Chmielewska E., Piotrowska K., Chłopek K., Modrzyński M., Stankiewicz W., Stasiak-Barmuda A., 2006. Stężenie pyłku traw w $2006 \mathrm{r}$. The grass pollen Mount In 2006. Alergoprofil, 2(3): 52-61.

M y s z k o w s k a D., 2006. Pyłek wybranych taksonów roślin w powietrzu Krakowa, 2001-2005. / Pollen of selected plant taxa in the air of Kraków, 2001-2005. In: Pyłek roślin w aeroplanktonie różnych regionów Polski. E. Weryszko-Chmielewska (ed.), Katedra i Zakład Farmakognozji z Pracownią Roślin Leczniczych Wydziału Farmaceutycznego Akademii Medycznej w Lublinie, pp. 21-30.

N o r r i s-H i 11 J., E m b e r 1 i n J., 1991. Diurnal variation of pollen concentration in the air of north-central London. Grana, 30: 229-234.

O b t u ł ow i c z K., S z c zepanek K., S z c zeklik A., 1990. The value of pollen count for diagnosis and therapy of pollen allergy in Poland. Grana, 29: 318-320.

Pi o trow s k a K., 2005. Wpływ opadów deszczu na koncentrację pyłku traw i pokrzywy w powietrzu Lublina. / The effect of rainfall on grass and nettle pollen concentration in the air of Lublin. Materiały V Ogólnopolskiej Konferencji Naukowej „Biologia Kwitnienia Roślin i Alergie Pyłkowe", Lublin: pp. 89.

P i o t r o w s k a K., 2006. Kalendarz pyłkowy dla Lublina, 1995-2000. / Pollen calendar of Lublin, 1995-2000. Acta Agrobot. 59, 1: 529-538.

$\mathrm{Pu}$ c M., P u c M., 2004. Allergenic airborne grass pollen in Szczecin, Poland. Ann Agric Environ. Med. 11: 237-244.

R a p i e j k o P., 2003. Medycyna a palinologia. In: Palinologia. S. Dybova-Jachowicz, A. Sadowska (ed.), Kraków, Inst. Botaniki PAN, pp. 63-68.

Rapiejko P., Wojdas A., Kantor I., Zielnik-Jurkiewicz B., Lipiec A., 2003. Progowe stężenie pyłku 
traw niezbędne do wywołania objawów uczuleniowych. / Threshold grass pollen concentration necessary to evoke allergic symptoms. Alergia, 2, 17: 60-62.

Rapiejko P., Lipiec A., Wojdas A., Jurkiewicz D., 2004a. / Threshold pollen concentration necessary to evoke allergic symptoms. Int. Rev. Allergol. Clin. Immunol. 10, 3: 91-94.

Rapiejko P., Lipiec A., Malkiewicz M., Chłopek K., Jurkiewicz D., 2004b. Wcześniejszy początek i dłuższy czas trwania sezonu pylenia traw. / The earlier beginning and longer duration of grass pollination season. Alergia, 3, 21: 61-62.

Ross-Codinachs M., Juarez-Cervera M., Torres J. N. J., 1992. An aerobiological study of pollen grains and fungal spores of Barcelona (Spain). Aerobiologia, 8: 255-265.

R u t k o w s k a B., 1970. Badania prowadzone w Polsce w zakresie biologii traw. / Research in grass biology conducted in Poland. Post. Nauk Roln. 5: 51-66.

S p i e k s m a F. Th. M., 1989. Airborne pollen concentrations in the European Economic Community (EEC). VI. Poaceae (Grasses) 1982-1986. Aerobiologia, 5: 38-43.

Spieksma F. Th. M., Corden J.M., Detandt M., Millington W. M., Nikkels H., Nolard N., Schoenmakers C.H.H., Wachter R., de Weger L. A., Willems R., Emberlin J., 2003. Quantitative trends in annual totals of five common airborne pollen types (Betula, Quercus, Poaceae, Urtica and Artemisia), at five pollen-monitoring stations in western Europe. Aerobiologia, 19: 171-184.

S t a c h A., 1997. Dobowe wahania stężenia pyłku wybranych taksonów alergogennych w powietrzu nad Poznaniem w 1996 roku. / Diurnal variations of pollen concentration of selected allergenic taxa in the air of Poznan in 1996. In: I Ogólnopolska Konferencja Naukowa-Biologia kwitnienia, nektarowania i zapylania roślin. Lublin. pp. 197-203.

S t a c h A., 2006. Pyłek wybranych taksonów roślin w powietrzu Poznania, 2001-2005. / Pollen of selected plant taxa in the air of Poznań, 2001-2005. In: Pyłek roślin w aeroplanktonie różnych regionów Polski. E. Weryszko-Chmielewska (ed.), Katedra i Zakład Farmakognozji z Pracownią Roślin Leczniczych Wydziału Farmaceutycznego Akademii Medycznej w Lublinie, pp. 31-48.
S yrigou E., Z an ik ou S., P a p a g e orgi ou P. S., 2003. Grasses, olive, parietaria and cypress in Athens: Pollen sampling from 1995 to 1999. Aerobiologia, 19: 133-137.

Ś p i e w a k R., 2001. Monitoring pyłkowy - jego znaczenie kliniczne w praktyce lekarza dermatologa i alergologa. / Pollen monitoring - its clinical relevance for dermatologists and allergists. Przew. Lekarza, 3, 27: 128-131.

W ery s z k o-C h m i e lew s k a E., Pi o trow sk a K., 2004. Airborne pollen calendar of Lublin, Poland. Ann Agric Environ. Med. 11: 91-97.

Werys zko-Ch mi e lew ska E., Pi o trow ska K., 2006. Pyłek wybranych taksonów roślin w powietrzu Lublina w latach 2001-2005. / Pollen of selected plant taxa in the air of Lublin in the years 2001-2005. In: Pyłek roślin w aeroplanktonie różnych regionów Polski. E. Weryszko-Chmielewska (ed.), Katedra i Zakład Farmakognozji z Pracownią Roślin Leczniczych Wydziału Farmaceutycznego Akademii Medycznej w Lublinie, pp. 105-107.

\section{Pyłek traw (Poaceae) w powietrzu Sosnowca w latach 1997-2006}

\section{Streszczenie}

Praca przedstawia wyniki analizy sezonów pylenia traw w latach 1997-2006 w Sosnowcu. Badania prowadzono metodą wolumetryczną aparatem typu Burkard. Długość sezonów pyłkowych wyznaczono metodą $98 \%$. W pracy oceniono wpływ warunków meteorologicznych na termin rozpoczęcia i długość sezonów pyłkowych traw. Początek sezonów pyłkowych rejestrowano między 23.04-23.05. Wykazano że średnia długość sezonu pyłkowego wynosiła 138 dni. Najwyższe stężenie dobowe stwierdzono w 2000 roku (495 ziarn $\mathrm{w} \mathrm{m}^{3}$ ), najwyższe sumy roczne w 2002 i 2000 roku. Okres maksymalnych stężeń notowano w czerwcu i pierwszej połowie lipca. Badania rytmiki dobowej pyłku traw wykazały najwyższe wartości pomiędzy $7^{\mathrm{oo}}-11^{\mathrm{oo}}, 13^{\mathrm{oo}}-17^{\mathrm{oo}}$ i $19^{\mathrm{oo}}-21^{\mathrm{oo}}$. 